\title{
Tšuktšid I
}

\section{$\underline{\text { Ülo Siimets }}$}

Tulles 1969. aastal Koo-

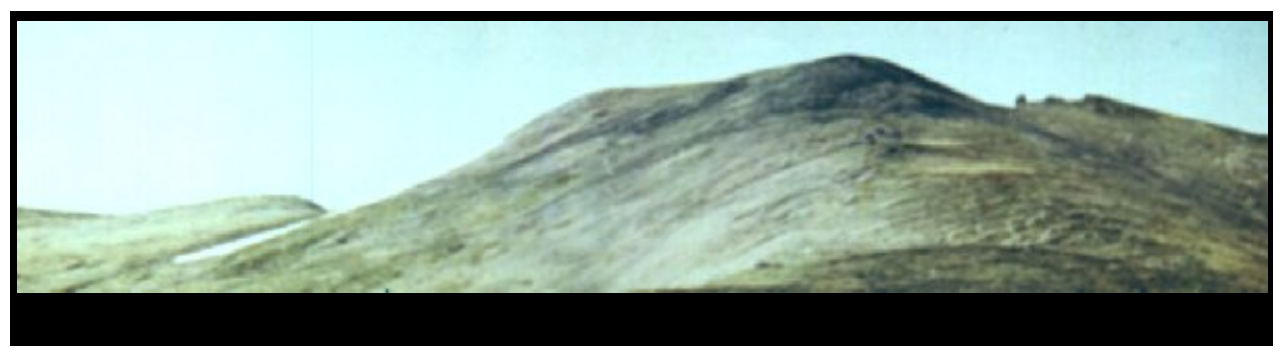

la poolsaarelt suusa-

matkalt, kohtasin Peterburis, tollases Leningradis, tšuktši neidusid, kes õppisid Põhjarahvaste Instituudis. Sellest sai alguse sõprus mõnede eestlaste ja tšuktšide vahel. Hiljem külastasid neiud eesti tudengeid Tartus, tekitades elevust tudengite ühiselamus.

Pärast Põhjarahvaste Instutuudi lõpetamist 1970. aastal sõitsid tüdrukud kodumaale tagasi ja saatsid meile küllakutse. Me ei jätnud oma sõbraga seda soodsat võimalust kasutamata.

Oli ju Tšukotka piiritsoon ja seega sinna pääsemine raskendatud. Sõjaväekohustuse tõttu anti meile Tartu sõjakomissariaadi poolt Eestist kolmeks kuuks lahkumise luba. Tšukotkal saime tõendi, et meid on lubatud igaveseks elama Tšuktši Rahvusringkonda.

Võtsime tollasest Eesti Põllumajanduse Akadeemia Metsamajanduse teaduskonnast akadeemilise puhkuse ja sõitsime Tšuktšimaale.

Viibisin seega 1971. aasta jaanuarist alates kümme kuud Magadani oblastis Tšukotka poolsaarel Anadõri tundras.

Tšuktšidest teadsin tol ajal väga vähe. ENE polnud selleks ajaks veel $T$-täheni jõudnud.

Vene entsüklopeediast sain teada, et nad on paleoasiaadid ja tšuktše on kokku umbes 11 000 inimest.

Tartu Ülikooli raamatukogust sain Bogoras-Tani raamatu «Tšuktšid», aga praktiliselt ei olnud aega sellega tutvuda. Lugesin nii palju, kui aega oli ja aru sain, sest raamat oli vene keeles. Ma ei olnud sel ajal veel teeninud Nõukogude Armees, keskkooli vene keelest jäi väheseks ja selle tõttu oli raskusi vene keeles kõikidest asjadest arusaamisega.

Meelde jäi üks mõttetera Bogoras-Tanilt: «Tšuktše ei saa nimetada meie tsivilisatsiooni vaatepunktist korralikeks inimesteks. Nad söövad omaenda täisid, pesevad kusega ja lasevad koertel oma kausid puhtaks lakkuda. Nad tarvitavad söögiks põhjapõtrade kiinide vastseid. Karjused söövad vahel põhjapõtrade väljaheiteid segatuna mitmesuguste noorte taimede roheliste võrsetega. Kuid neil on omad arusaamad

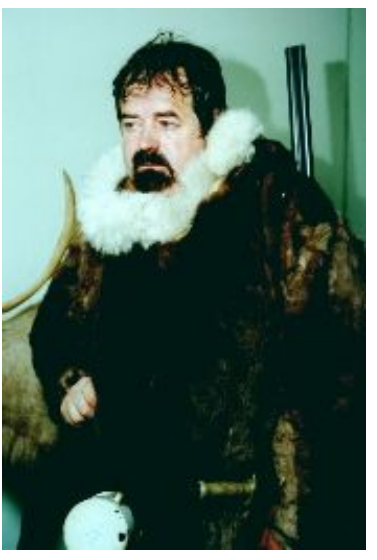
korralikkusest. Nad vaatavad vastikusega lehmapiima, sest peavad lehma räpaseks loomaks. Nad kinnitavad, et loomalihal on eriline ebameeldiv lõhn, mis sarnaneb lehmasita lõhnaga. Paljud nendest keelduvad minemast majja, kus keedeti loomaliha.

Teiselt poolt, kui tšuktšidele ütelda, et hülgelihal on ebameeldiv hais, siis nad omakorda vaidlevad vastu, öeldes: «Hüljes on puhas. Ta pidevalt peseb ennast puhtas vees, aga teie sööte oma räpaste loomade liha.ı"»

Samas raamatus oli ka kirjas, et Tšuktšimaa oli Tsaari-Venemaa ainukene territoorium, millele oli antud tegelik autonoomia ja mis oli jäänud venelaste poolt lõplikult vallutamata. Vastavalt Venemaa Seaduste Kogu ühele paragrahvile nimetati Tšuktšimaad Venemaa mitte täielikult alistatud territooriumiks «russkaja ne vpolne pokorjonnaja territorija» ja seal kehtisid kohalikud seadused. 
See maaosa, mis asus Tšauna ja Anadõri jõgedest lääne suunas, kandis nime "Tšuktšimaa". Sealsed elanikud, nagu kõik tšuktšidki, omasid teatud privileege otsustada oma asjade, sealhulgas ka tapmiste üle, vastavalt oma vanadele tavadele. Seda juhul, kui selline asi toimus nende territooriumi piirides.

Siberi vallutamine oli toimunud väga kiiresti. 1586. aastal rajati khaan Kutšumi riigi pealinna Tšingi-Turo varemetele Tjumeni kindlus.

62 järgmise aastaga jõudsid Tomski kasakad Ohhoota mere äärde, kuid edasi põhja nad ei suutnud tungida. Kõlõma jõe alamjooks jäi aastakümneteks piirijõeks. Tšuktšidepoolne vastupanu oli väga tugev.

Kui sõda oli kestnud peaaegu sama kaua kui terve Siberi vallutamine, oli Katariina II sunnitud järele andma Senati taotlusele ja Tšuktšimaa vallutamisest loobuma. 1771. aastal Anadõri kindlus lammutati ja 1778. aastal suudeti lõpuks sõlmida rahu, mida kumbki pool enam ei rikkunud.

Peterburist tuli korraldus valmistada riigivapid ja saata need tšuktšidele, et tšuktšid riputaksid need vapid oma rannikul puude külge ja näitaksid neid laevadelt maale tulnutele, et teadustada maade kuulumist Vene impeeriumile.

Tšuktšimaal olles selgus, et olukord muidugi päris nii ei ole, kui Bogoras-Tan oli kirjutanud. Paljud väited, õigemini enamus, vastasid tõele, aga eks aeg olnud edasi läinud. Sellest kõigest allpool.

Algul töötasin 4,5 kuud lehisepalkidest maja ehitusel, kusjuures palkidest majad varati nagu meil muiste spetsiaalse kirve abil. Palgid majade jaoks toodi laevaga Magadanist ja Vladivostokist. Ehitasime kahekorruselist 8-korterilist maja. See oli teine seda tüüpi maja Vaegi külas. Külas elas sel ajal 104 inimest ja küla koosnes põhiliselt väikemajadest suurusega 4 x 5-6 meetrit.

Nii nagu meil nõukogude ajal, oli olukord ka tšuktšide juures. Vastavalt plaanimajandusele hakati välja ehitama kolhoosikeskusi, kuhu koondati jarangadest (põhjapõdranahkadest tšuktši elamu) ümbruskonna elanikkond.

Seal oli see ka üks vahenditest, kuidas saada nomaadidest elanikkonda riigi kontrolli alla.

Külas asus põdrakasvatuskolhoosi keskus koos kolhoosi ladudega, külanõukogu, postkontor, diiselelektrijõujaam, katlamaja, kool koos kooliinternaadiga, klubi, haigla, kauplus, õmblustöökoda, leivaküpsetustsehh, hobuse- ja lehmafarm ning isegi saun.

Viimast kasutati küll ainult suvel, sest talvel ei suudetud sauna tšuktšide arvates lihtsalt soojaks kütta. Sel ajal, kui meie Vaegis viibisime, ei õnnestunud meil sauna külastada.

Kes seda sauna kasutasid, jäi meile teadmata, sest tšuktšide rahvatarkus oli: «Kui mustus küpseks saab, siis ta kukub ise maha.»

Peaaegu samuti suhtuti ka haiglasse. Seda kasutasid venelased ja teised läänest tulnud. Kohalikud tšuktšid kasutasid haiglat harva. Isegi lapsed sünnitati põhiliselt jarangades.

Vaegi külast radiaalselt mitmes, õigemini 9 suunas, paiknesid 300-500 km kaugusel põdrakasvatusbrigaadid. Sealseteks keskusteks olid jarangadest külad. Igas külas oli 7-12 jarangat. Jarangakülade juurest said alguse põdrakarjade toitumisretked karjamaadele ning teatud aja järel jõudis põdrakari siia tagasi. Karjas olles ja karjaga ringi liikudes magasid karjused telkides või lausa lahtise taeva all.

Jarangades elasid põhjapõdrakarjuste naised, lapsed ja nende isad-emad. Puumajadest külla ei soovinud enamus põdrakasvatajate sugulastest minna. 
Nende hulgas oli inimesi, kes ei olnud oma elu jooksul näinud puust maju.

Numbrite järgi oli karjakasvatusbrigaade 15. Tegelikkuses oli neid brigaade ainult 9 . Sotsialismi viljastavates tingimustes olid kuus põdrakarja muutunud nii väikseks, et nad liideti teiste karjadega.

Mina olin pärast maja ehitusttöid kuu aega madruseks laeval, mis vedas Anadõrist palke ja saematerjali Vaegi külla.

Edasi pakuti meile tööd kullakaevurina ja ketapüüdjana. (Keta - Kaug-Ida ja Kaug-Põhja jõgedes elav lõheline).

Kullaartellis oli võimalus teenida sel ajal väga suurt raha. Räägiti mehest, kes oli leidnud kullasoone ja teeninud mitusada tuhat rubla. Ta ei osanud rahaga midagi peale hakata ja kulutas seda, tellides endale ja sõpradele lennukiga tšarterreisid Moskvasse, et juua seal parimates restoranides, ning ostes Moskva Suure Teatri baleriinidelt erilisi balletietendusi.

Sel kullaartellil Dopolinas, kuhu meid kutsuti ja kuhu me ei läinud, läks ka hästi. Nad leid-sid kulda ja teenisid 20000 rubla ühe sessiooni jooksul (2,5 kuu jooksul). Artelli liikmetest olid paljud endised vangid, kes olid jäänud elama Kaug-Põhja pärast oma karistuse lõppemist. Ma arvan, et nende tõttu jäidki tundrasse kadunuks mõned brigaadi liikmetest. Nii et pole head ilma halvata - meie elud jäid alles.

Ka ketapüüdjad teenisid hästi. Püügisessiooni lõpuks kujunes nende palgaks 1500-2500 rubla kuus.

Võrdluseks võin õelda, et 2 aastat hiljem, pärast EPA lõpetamist, läksin tööle metsameistrina Tartu Metsakombinaati ja teenisin 1973. aasta kevadel 80 rubla kuus.

Tšuktšimaal me ei olnud raha peal väljas, sest meid huvitas kohalik eluviis ja põdrakasvatus. Loobusime kõikidest pakutavatest hiilgavatest võimalustest. Meid nimetati lollideks ja öeldi, et isegi tšuktši noored mehed ei saa karjas hakkama, aga te ei ole ju isegi tšuktšid, kuid soovite karja minna.

Edasi õnnestus ikkagi pika kauplemise peale pääseda põdrakarja, kuigi üks eestlane ühte ja teine teise brigaadi. Nii oli kohalikele ohutum, sest mine tea, mis need suurt kasvu «yankid» koos olles teha võivad. Millisesse brigaadi kumbki läheb, see selgus liisutõmbamise teel.

Ma tegin ligi nelja ja poole tuhande pealise põhjapõdrakarjaga kaasa umbes 5000-6000 kilomeetri pikkuse tiiru mööda Tšuktši poolsaart. Karjusteks olid selles brigaadis 5 tšuktši ja mina. Ametinimetuse järgi olin karjus-zootehnik, mis tähendas seda, et pidin haigeid loomi süstima ja vajaduse korral ka opereerima.

Põhiliseks haiguseks oli põhjapõtradel kapõtka. See haigus tekkis põhjapõtradel karvavahetuse ajal, kui nad vigastasid jalgu, kuhu sattusid pisikud. Haiguse tõttu olid väga paljudel kariloomadel jalad kuni põlvedeni paistes. Ravimiseks tuli põhjapõder kinni püüda, skalpelliga mädapaised avada ja pärast steriliseerimist haavad uuesti kinni õmmelda.

Saatuse tahtel sattusin Tšuktšimaa kolhoosi «Put k kommunismu» («Tee kommunismile») kõige mahajäänumasse põhjapõdrakasvatuse brigaadi.

Ühelt poolt oli see halb, kuna mahajäänud brigaadi liikmete keskmine palk oli teiste brigaadide palgast kohati kolm korda väiksem. Teiselt poolt olid meie brigaadis säilinud ürgsed tavad, mis olid seotud rituaalsete toimingute, sealhulgas ohverdamiste läbiviimisega. Oli asju ja toiminguid, millest ma alles hiljem aru sain, olles tutvunud sellealase kirjandusega.

Minu arust on tänaseni liiga vähe tähelepanu pööratud tšuktšide usundile. Tšuktšid on üks vähestest rahvastest endise Tsaari-Venemaa ja Nõukogude Liidu territooriumil, kes jäid ristimata. Nende usundi järgi on kõikidel asjadel, taimedel, puudel, loomadel hing. Selles suhtes sarnaneb nende usk meie taasavastatud taarausuga, mida me nimetame eestlaste vanaks 
usuks, olles selle usu püüdnud kildudest kokku panna. Teame ju me enne ristiusu vägivaldset kehtestamist elanud eestlastest väga vähe. Põhilised märkmed meie vanast usust on jõudnud tänapäevani Läti Henriku kroonika vahendusel. Mis oli varem, sellest teatakse väga vähe.

Tšuktšimaal olles pidasin matkapäevikut, kuhu panin kirja kõik tähtsamad sündmused, jutud ja legendid. Järgnevalt toongi ära mõningaid väljavõtteid päevikust, mis käsitleb minu seda eluperioodi.

\section{Kohtumine Leningradis}

Kolmandat päeva puistas lund. Sadu oli neid tabanud juba Koolal ja tundus, et üle kogu selle tuhandete ruutkilomeetrite suuruse maa-ala Koolast Leningradini on laotunud paks pilvevaip, millest hõljus alla valgeid kübemeid.

Poisid hulkusid sihitult mööda linna tänavaid. Igasse poodi oldi juba sisse vaadatud, igal tänavanurgal tüdrukuid kiigatud ja nüüd hakkas igavus kallale tükkima. Võib-olla oleks õigem olnud koos teiste matkakaaslastega koju sõita. Miks olid nad Leningradi jäänud? Ainult selleks, et talvist koolivaheaega veel pikemaks ja huvitavamaks muuta.

Kuna üks poistest oli ameti poolest tudeng-katlakütja, siis andsid tema suured sissetulekud (35 rubla stipendiumi ja 120 rubla palka) selleks hiilgava võimaluse.

Oli ju pärast suusamatka tervelt 70 rubla alles jäänud. Konjakipudel restoranis maksis ainult 4,80 rbl. Ja poest võis konjakit veelgi odavamalt saada. Küsimus oli rohkem selles, et konjak oli üks kaupadest, mida poodidesse ei jagunud.

«Tuleks kiiremas korras midagi ette võtta,» ütles üks poiss teisele. Ta oli $180 \mathrm{~cm}$ pikk, siniste silmade, süsimusta täišabeme ja üle õlgade ulatuvate pikkade juustega šatään. Tema oligi see «kõrgepalgaline» tudeng.

«Lähme teritame natukene mõistust,» vastas teine habemik. Ta oli oma kaaslasest paar senti pikem ja tunduvalt laiaõlgsem. Habemetutt lõua otsas oli tal täielikus kooskõlas tema suure, etteulatuva kartulininaga. Mehine nina pidi olema nende perekonna uhkus iidsetest aegadest tänaseni. Juuksed olid tumedamad kui kaaslasel ja ei ulatunud lokikestena õlgadeni.

Tema esiletungivale «nosplile» toetusid vägevad sarvraamidega prillid - filosoof 19. sajandist.

Vesteldes olid nad jõudnud sillale, kus igas sillanurgas seisev mees püüdis taltsutada metsikut hobust, ja teisel pool silda oli näha pikka järjekorda, kes ootas oma aega restorani pääsemiseks. Oli ju veel see kaunis aeg, kus osa inimesi olid võrdsemad kui teised, kus tutvus oli tähtsam kui raha. Ka restorane ja baare ei olnud iga nurga peal ning õlut võis saada harva või siis ainult õllesaalist.

Osa inimesi tammus jalalt jalale, osa hüples üles-alla, üks noorpaar mängis kukekesi, kareldes ühel jalal ja püüdes õlalöökidega teist tasakaalust välja viia.

Uksel rippus ilustusena silt «VABU KOHTI EI OLE», kuid inimesed ei kaotanud lootust ja ootasid kannatamatult oma tundi, et siis mõningad grammid toniseerivat mürki oma kehasse ringlema lasta.

«Eesrindliku võitleja osa võib täita ainult mees, kellel on oma eesrindlik teooria,» torises filosoof. «Teeme nalja ka.»

Ta ei pööranud mingit tähelepanu ümbritsevale rahvahulgale, vaid sammus restorani ukse juurde ja asus taskust leitud võtmega ukse peale koputama. 
Ruumi sisemusest ilmus kuldrandiga mütsi kandev šveitser ja küsis, mida koputaja soovib.

Teda tabas tundmatus keeles sõnavaling: «Perkeli poika, kas vabu kohti ka on?»

Šveitserit hämmastas selline lähenemine ja tema vanainimese-näkku ilmus nõutus. Mida need tundmatud tahavad? Ukse peal on ju selge sõnaga kirjutatud, et vabu kohti ei ole, aga neid ei paistnud see häirivat.

Esimese kõrvale ilmus teine, veel imelikum habemega olevus, kellel pikad juuksed lehvisid tuules ja kes tegi kurja häält, mis tuli nagu tõrre põhjast «Kas saab vabu kohti või ei?»

«Vist ikka välismaalased,» mõtles arvatavasti vanake, «parem neid mitte pahandada.»

Tema punetavasse näkku ilmus midagi lipitseva naeratuse taolist. «Prošu gospoda,» («palun härrased») ja ta avas sügavasti kummardades ukse.

Poisid viskasid presendist jopid seljast ja läksid villaste kampsunite väel saali.

«Kõige soodsam olukord indiviidi esilekerkimiseks on kriitiline olukord, kus tekib nõudmine nende järele. Uus olukord nõuab talendi esitamist maksku mis maksab,» torises filosoof jälle, kui nad lauda istusid.

Saal oli peaaegu tühi. Ainult seinaäärsed lauad olid hõivatud ning poisid istusid saali keskel olevasse lauda. Ukse kõrval nurgalauas istusid neegrid, kes vahtisid üleolevalt kõrvallauas istuvaid apteegiblonde naisi. Ühe neegri näol ilutsesid neli üle näo ulatuvat armi.

"Vist on teisel näol võitluse jäljed mõne taolise "valgepäise lõviga»," sõnas filosoof oma kaaslasele, viibates peaga naistelaua poole, "vaata, nad paistavad sinust päris huvitatud olema.»

«Neid huvitab ainult raha - peavad meid välismaalasteks,» vastas täišabe, «sellise käest võid midagi kaasa ka haarata.»

Üks valgepea õgis neid tõepoolest silmadega. Ta oli umbes kolmekümne-aastane, väga kireva sõjamaalinguga daam. Silmade külge olid kleebitud «kärbsejalad», suu oli suureks ja punaseks värvitud, nagu oleks ta äsja lõpetanud vereimemise oma ohvri kaelast. Nägu oli paksult krohvitud, kuid läbi krohvikihi oli näha eelmise öö pummeldamise jälgi. Daam hakkas pilgutama silma, ning täišabe pööras oma pilgu kõrvallauale.

Seal istus üks kõhn, kaunis neiu kolme noormehe seltsis ja kirjutas või joonistas midagi paberile. Natukese aja pärast kutsus ta kelneri ning andis mehele mingid paberilehed. Kelner sammus habemike juurde ja ulatas paberilehed poistele. Joonistuspaberitele olid lühikese ajaga ilmunud noormeeste portreed ja need olid väga originaalilähedased. Poisid palusid kelnerit viia nende arvelt neiule pudel šampust.

«Oleme ebavõrdses seisus, kolm kahe vastu,» ütles täišabe filosoofile, «ja pealegi ei ole meil kahekesi ühega midagi peale hakata.»

Korraga tippisid saali kaks väikest kasvu pilusilmadega tüdrukut.

«Vist vietnamlannad,» ühmas filosoof, «pärast viimaseid Hanoi pommitamisi on neid Liitu rohkesti toodud.»

Tüdrukud said kohad kahe mereväemundris ohvitseri juurde. Nad tellisid pudeli šampust, vestlesid omavahel mingis arusaamatus keeles ja ei pööranud mingit tähelepanu saalisolijatele.

Poisid olid juba tükk aega tagasi oma konjaki kätte saanud ja natukene ka klaasi jõudnud tõsta. Pea surises õrnalt ja keha hakkas soojaks minema.

Orkester hakkas mängima foksi. Paarikaupa kadusid inimesed laudadest tantsupõrandale. Istuma jäid ainult kaheksa nurgalaua neegrit, kolm asiaati ja kaks karvast eestlast. Kõiki 
neid valdas vist mingisugune alaväärsuskompleks. Eestlasi see, et nad olid tulnud restorani suusasaabastes ja kampsunites, teistel noormeestel ei jätkunud lihtsalt kiirust ja pealehakkamist endale kaaslaste leidmiseks.

Nii nad istusid ja vaatlesid tantsijaid, kellest enamus tammus jalalt jalale, kõigutades ennast muusika taktis. Paljud paarid tuikusid juba väga energiliselt. Ainult üksikud püüdsid näidata, kuidas peab tantsima. Muusika katkes järsku ja seltskond valgus tagasi laudadesse.

«Inimene on armastuse objekt, sest ta on eesmärk iseendas, mõistuslik ja armastuseks võimeline olend. See on soo, see on mõistuse käsk,» tsiteeris filosoof Feuerbachi.

«Noh, olgu,» vastas talle kaaslane, tõusis püsti ja astus meremeeste laua juurde, sest orkester oli hakanud jälle mängima. Ta palus ühe neidudest tantsima.

«Kas Te olete Vietnamist,» küsis ta, kui nad olid teinud paar tantsusammu.

«Ei ole,» vastas neiu.

«Kust siis?»

«See on saladus.»

«Huvitav miks?»

«Nii on lihtsalt parem,» vastas neiu midagi pikemalt selgitamata.

Peagi oli tantsijate hulgas näha filosoofi. Poisid olid juba heas tujus ja ei märganudki enam oma suusasaapaid ja kampsuneid. Need oleks nagu asendunud peokingade ja ülikonnaga. Kuigi nad moodustasid asiaatidest neidudega kummalised paarid, ei seganud inimeste pilgud neid enam.

Tantsima tulid ka valged «emalõvid», kes olid meremehed endale kaaslasteks saanud. Üks neist pilgutas täišabemele meeleheitlikult oma värvitud silmi.

Algas jälle vaheaeg ja kõik läksid kohtadele. Poisid arutasid maast ja ilmast ning olid jõudnud just salapärase heeliumi juurde, kui korraga kuulsid laua kõrvalt naise häält: «Kas võib Teid tantsima paluda?» Laua kõrval seisis vesinikublond naine ja asetas käe täishabeme õlale.

Orkester oli välja kuulutanud daamide valiku.

Poistele tuli see tõepoolest natuke ootamatult, sest Tartu restoranis «Volga» võis naiste valikut ette tulla ainult naistepäeval.

Poiss juhtis daami tantsupõrandale. Naine oli lüheldast kasvu, sale, rohekate silmadega. Ta liibus tihedalt noormehe vastu ja ütles: «Mina olen Jelena. Kuidas sind hüütakse?»

«Ülo,» vastas täishabe.

«Kuidas?» ei saanud blondiin aru.

«Ü, L ja O.»

«Ilo.»

«Mitte Ilo, vaid Ülo.»

Kui naine pärast mitmekordset kordamist nime hääldamisega ikka toime ei tulnud, siis lubas noormees ennast armulikult Juraks kutsuda.

«Kas te olete Soomest?»

«Miks sa nii arvad?» 
«Noh, ma kuulasin, kuidas te omavahel rääkisite. Kõlab soome keele moodi. Pealegi olete niisugused karvased ja ronite suusasaabastes restorani.»

«Päris nii see ka ei ole. Ka Nõukogude Liidus leidub karvaseid ja suusasaabastes.»

«Aga need ei julge tulla suusasaabastes «Inturisti» restorani, ning pealegi ei lasta neid nii sisse. Ka räägite te vene keelt nii koleda aktsendiga. Venemaal räägitakse siiski korralikku vene keelt.»

«Kas see ei ole ükskõik, kust me oleme?»

«Noh, päris ükskõik see ka ei ole. Mul on suur korter ja kaunis sõbranna vaba, võiks peo teha.»

«Eks me vaata.»

Orkester lõpetas ja nad läksid tagasi laudadesse.

«Heiki,» ütles Ülo filosoofile, «meile pakutakse vaba korterit ja vägevat pidu. Sulle on blondi sõbranna välja pakutud.»

«Kurat, nii vana kõõmaga ma küll sebima ei taha hakata.»

Ligi kolmveerand tundi oli saalis valitsevaks üha kõvemaks muutuv häälekõmin, sest orkester oli läinud puhkama.

Siit-sealt hakkas kostma ülemeelikuid naeruturtsatusi ja kilkeid. Mõni püüdis hakata rahvast lõbustama rahvalike lauludega, aga kuna ühislaulust asja ei saanud, siis kelnerid vaigistasid üritajad kähku maha.

Orkester võeti vastu tormiliste ovatsioonidega, aga tantsust ei tulnud enam midagi välja. Inimesed tuikusid ja müksisid kogu aeg üksteist. Tantsust oli niipalju kasu, et õnnestus tõmmude neidude nimed teada saada. Pikemat kutsuti Niinaks ja lühemat Tanjaks.

Aeg möödus restoranis lausa lennates. Tantsiti naistega kord ühest, kord teisest lauast. Kui nad järjekordselt lauda tagasi jõudsid, nägid nad, et «vietnamlannad» valmistuvad lahkuma.

Ka nemad kutsusid kelneri ja jäid ootama arvet. Kui nad selle asjaga ühele poole said ja riidehoidu jõudsid, olid neiud juba kadunud. Poisid said jopid kätte ja astusid õues valitsevasse pimedusse. Nad arvasid, et neiud on lahkunud, kuid önneks silmasid neid Nevski prospektil aeglaselt kõndimas ja aeg-ajalt tagasi vaatamas. Koos jalutasid nad mööda tuledes säravat Leningradi. Mõne aja järel olid nad jõudnud neidude märkamatul juhtimisel mingile väljakule. Prožektorikiirtes kõrgus taeva poole hiiglaslik monument.

«Ta nüüdki meie ees kui hiid, iidse mõttelaeva giid,» tsiteeris Ülo ühte Rimmeli luuletust.

Lähemale minnes selgus, et ei olegi «Tema» ja tegemist on hoopis Kirovi kujuga.

«Mis sest, et pole «Tema», aga suur on ta siiski,» vabandas Ülo ennast välja.

«Mida te seal oma keeles vadistate?» küsis Niina.

Selle peale püüdis Ülo tõlkida eespool nimetatud tsitaati vene keelde, kuid sai Tanjalt pahase vastuse, et kuidas teie luuletajad julgevad nii suurt inimest tituleerida «iidse mõttelaeva giidiks» - on ju seltsimees Lenini ideed läbi aastasaja kaasaegsed ja järjest rohkem leitakse tema avaldamata käsikirju, kus on kirjas, kuidas me elama peaksime, ja kui nii tehtaks, nagu tema ette kirjutas, siis elaks me ammu kommunismis.

Kahjuks aga tehakse kõike valesti ning ei järgita suure juhi õpetussõnu ja sellest see mõningase kauba puudus ja üldse kõik elu halvad küljed on sellest tingitud. 
Sellest sai aga alguse suur võistu luuletuste lugemine. Poisid teadsid peast ainult keskkooli kohustuslikku lektüüri ja langesid kähku mängust välja, aga neiud muudkui lugesid ja lugesid. Puškin, Lermontov jne olid neil peatükkide kaupa pähe õpitud.

Lõpuks poisid tüdinesid, kuulutasid mõlemad neiud võitjateks ja nende tulemused viigiliseks, ennast kaotajateks ja palusid selgitust, kustkohast neiud nii hästi vene kirjandust tunnevad. Selgus, et nad õpivad Leningradi Põhjarahvaste Instituudis vene keele õpetajateks ja siiamaani ei ole oma rahvale häbi teinud, õppides ainult väga headele hinnetele.

Neidude targal juhtimisel kõnniti mööda tänavaid, mindi mingite kangide alt läbi ja jõuti ühiselamu hoovile. Tüdrukud palusid poisse oodata ja kadusid majja. Natukese aja pärast tulid nad tagasi ja kutsusid noormehed kaasa. Nad viidi ühte pimedasse tuppa, kus võis eraldada pimeduses oma paari tosinat voodit, milledest kaks olid tühjad.

«Hommikul näeme,» sädistasid nad naerdes ja lahkusid toast.

«Kaevaku teised, et aeg on kuri, mina kaeban, et see on armetu, sest selles puudub kirg,» tsiteeris Heiki torisedes jälle kedagi. "Inimmõtted on õblukesed ja õrnad nagu pitsid, nad ise haletsusväärsed nagu pitsiheegeldajad. Mõtted nende südames on liiga armetud, et olla patused. Vagla juures peetakse võib-olla patuks sääraste mõtete olemasolu, inimeste juures mitte, sest ta on loodud jumala näo järgià

Ma tunnen ennast kõige paremini õhtuti, hetkel, mil ma tule kustutan ja teki üle pea tõmban, siis tõusen ma veel kord üles, vaatan rahuloluga veel kord ringi, ja seejärel head ööd ja sulekott üle pea.»

«Noh, kes teab, milleks see hea oli,» vastas Ülo talle lahti riietudes ja voodisse ronides, head ööd, eks hommik ole õhtust targem.»

Hommikul ärkasid nad sagina ja uste paugutamise peale. Esimesel hetkel ei saanud nad arugi, kuhu nad olid sattunud. Toas siblis ringi oma paarkümmend asiaati, kõik ühtemoodi sinkjasmustade peade ja pilukil silmadega. Kõigil oli hirmus kiire. Poisid rääkisid kord vene keeles, kord mingites muudes keeltes. Siis meenusid eelmise õhtu südmused ja sattumine siia tuppa.

Kui tormlemine oli vähenenud, tõusid ka habemikud üles ja läksid pesema. Tagasi tulles leidsid nad, et poisid olid lahkunud ja nende asemel istus toas eileõhtune tuttav - Niina.

«Tere hommikust! Kuidas magasite?»

«Tere, tere! Ei olnud viga,» vastas Ülo, «ainuke viga oli selles, et hommikul leidsime ennast «telgis» magamas.»

«Kuidas telgis?» ei saanud Niina aru.

«Ah, ära tee välja, niisama lõõbib. Kus Tanja on?» küsis filosoof turtsudes.

«Tema kiirustas loengule. Mina olin sunnitud poppi tegema, sest keegi peab ju teiega tegelema.»

«Lähme sööma,» ütles selle peale Ülo ja nad läksid tudengite sööklasse. Pärast pidi ka Niina loengule minema ja poisid hakkasid liikuma Nevski prospekti suunas. Kartes neidusid silmist kaotada, olid nad suure kiiruga restoranist väljunud ja oma kotid sinna riidehoidu unustanud.

Bussi ootamine ja sellega kesklinna jõudmine võttis tükk aega.

Kuna restoran asus hobustega silla lähedal, ei olnud selle leidmisega vähemalt raskusi.

Poisid võtsid prae ja kuiva veini, andsid uksehoidjale hea töö eest viis rubla ja läksid metroosse. 
Seal selgus, et see öö oli siiski oma jäljed jätnud. Raha oli ootamatult otsas. Nad pöörasid oma taskud pahupidi, aga seda puuduvat ühte kopikat ei olnud kusagil.

Tähelepanelikult uurisid nad põrandat, et võib-olla on keegi selle ühe kopika ära kaotanud, aga mida ei olnud, seda ei olnud.

Nad läksid korrapidaja juurde, näitasid oma 9 kopikat ja Ülo ütles: «Vabandage, meil kadus rahakott ära. Rohkem taskus ei ole, aga rongi peale on vaja jõuda.»

«Andke siia ja sõitke,» ütles kontrolör neid pealaest jalatallani silmitsedes.

«Aitäh,» vastasid poisid ja kiirustasid eskalaatorile.

«Hea, et meil piletid ainult komposteerimist vajavad,» sõnas Ülo, kui nad vagunisse olid istunud.

«Tartusse jõudes peab jälle mitu ööd lihakombinaadis liha laadima,» kirus Heiki. «Kas see kõik tasus ära niisuguse mageda õhtu eest?»

«Õndsad on need, kes on vaimust vaesed, ja kes teab, milleks see veel hea oli,» vastas Ülo talle.

Keegi ei teadnud siis veel, et sellest tutvusest saab alguse reis maailma otsa, igavese lume ja igikeltsa maale.

\section{Me oleme ühest verest, sina ja mina}

Sopka otsas istusid kaks meest. Üks oli lühikest kasvu umbes $150 \mathrm{~cm}$ pikkune, mongoliidsete näojoontega, tumedate pilusilmadega mees. Tema karusnahksele kuhfljankale (tšuktši üle pea aetav pikk riietusese) oli peale tõmmatud presentürp. Jalas olid mittemärguvast kuldkollasest hülgenahast kaunistustega torbased (nahksaapad). Pea oli kaetud karusnahkse kapuutsiga, millele oli tõmmatud presentkapuuts. Jalge ees maas oli jahioda.

See oli väga vana. Kui vana, seda ei teadnud keegi. Oda pärandati mehele kui perest väljavalitud pojale ja nii olevat see toimunud põlvest põlve. Vahel oli selleks väljavalitud pojaks kõige vanem, mõnikord mõni teine pereliige.

Valiku aluseks olevat inimese võime «hingedega» suhelda. Igas põdrakarjuse peres või vähemalt igas jarangade külas pidi olema vähemalt üks selline inimene. Mõnes laagris olevat selliseid inimesi mitu.

Tšuktšid ise räägivad, et niisugused «väljavalitud lapsed» on äratuntavad juba varases nooruses. Sellised lapsed ei vaata rääkides kõnelejale otsa, vaid vaatavad midagi, mis asub rääkijast tagapool või üleval. Nende laste pilk pidi olema erinev teiste laste pilkudest. Mõnede pilk pidi otsekui sädelema. Eriti terav pidi olema pilk nendel lastel, kelledest saavad hiljem päris šamaanid, sest nendel on vaja oma töö tõttu näha just "hingi» ja "vaime». šamaanid pidid «hingede» nägemisega hakkama saama isegi pimeduses.

Odatera oli kaunistatud maagiliste ornamentidega. Paljud märgid olid aastatega odatera pealt maha kulunud.

Tšuktši jutu järgi olid selle tera peale kirjutatud sõnad vanas tšuktši keeles. Selline tähestik olevat Tšuktšimaal olnud enne venelaste tulekut. Venelased olevat viinud tšuktši keele üle kirillitsale, et ise aru saada, mis kirjutatud, sest ega nad viitsi teiste keeli selgeks õppida. (Nõukogude-aegne entsüklopeedia väidab, et tšuktšidel puudus enne venelaste tulekut oma tähestik. Tšuktšid said oma kirjakeele alles 1931. aastal. Lennart Meri raamatu «Virmaliste väraval» järgi oli tšuktši tähestiku looja Bogoras Tan). 
Tartu ülikooli filoloogiatudengitele esitatakse loengus andmeid, et mõningatel põhjarahvastel oli oma tähestik. Näiteks tuuakse komidel olnud tähestikku ja kirjakeelt.

Vene misjonär Permi Stefanus kasutas seda pühakirjade ja muude tekstide kirjutamiseks ja ülesmärkimiseks. Hiljem on Moskva ikoonimeistrid selles tähestikus pühapiltidele nimesid kirjutanud. Veel hiljem pandi see tähestik kirikujuhtide poolt kirikuvande ja keelu alla. Selles kirjas kirjutatud raamatud põletati. Selle tähestiku aluseks oli olnud põhja-iraani tähestik.Võib-olla oli oma kiri ka teistel põhjarahvastel.

Tavaliselt oli odatera kaetud narmastega kaunistatud nahktupega. Narmad olid lõigatud ühest naharibast, nii et nad moodustasid inimfiguurid, kes olid ühtlasi kaitsevaimudeks. Selleks oli nahariba lõigatud neljaks narmaks. Narmaste otsa olid seotud sõlmed. Odatupe külge kinnitatud ülemine osa moodustas pea. Äärmised narmad olid lühemad, olles käteks, keskmised, pikemad, olid jalgadeks.

Sellist kaitsevaimu kutsuti kipur'iks. Neid kujukesi kasutati kaitsevaimudena mitmetes kohtades, näiteks jarangade uste lähedal, magamisasemete polog'ide juures. Tähelepanelikul vaatlemisel oli neid märgata isegi riietusesemete kaunistamisel.

Paljudel meestel olid talvel peas kahe terava tipuga mütsid, mille teravad nurgad olid nagu koerakõrvad. Koerakõrvade otsas rippusid kipurid, mille valmistamisel oli kasutatud sõlmede asemel naharibade otsa õmmeldud nööpe.

Meestel oli tavaliselt vööl ka üks nahkkotikene, mille sees oli kaheharulisest puust tehtud kipur.

Oda külge oli terast allapoole kinnitatud kuljus, mis liikumisel pidevalt kõlises. Kuljus pidi oma helinaga peletama halba vaimu ketlja't.

Oda vabastati tupest ainult rituaalsete ohverduste ajal. Muul ajal oli ta tupes ja mees kandis teda kogu aeg endaga kaasas.

Mehe kõrval oli hülgenahkne seljakott ja üle kõige oli tõmmatud plastikkile. Tema vööl rippusid nuga, lumelamba sarvest voolitud luulusikas, kruus, nahkkott padrunitega, tubakakott koos tikkude, tulekivi ja niidi-nõelaga ning veel mõned nahkkotikesed.

Mehe kõrvadesse olid tehtud augud, milledest olid läbi torgatud heinakõrred.

«Augud on selleks, et saaksin kõrvarõngaid kõrva riputada, kui tahan ilus välja näha. Ilma kõrteta kasvavad augud kinni,» oli mees vastanud küsimusele, miks tal kõrred kõrvas on.

Teised karjused irvitasid seda kuuldes ja ütlesid, et Ejgeli riputab kuljused kõrva, kui ta tantsima läheb. Nii, et mehe nimi oli Ejgeli. Tal oli hea ja soe, ning ta magas.

Tema kõrval istus $180 \mathrm{~cm}$ pikkune, euroopalike näojoontega, siniste silmade ja musta täishabemega mees. Tal oli seljas kampsun, millele oli tõmmatud presendist kufljanka või seda meenutav riietusese, jalas pika säärega kummist kalamehesaapad, seljal rippus presendist seljakott, ning üle kõige oli tõmmatud plastikkile. Ka temal oli vööl nuga, mis suuruselt sarnanes väikese mõõgaga, luulusikas - ja suur emaileeritud liitrine kruus. Luulusika, mis oli nagu Ejgelil tehtud lumelamba sarvest, olid talle kinkinud tuttavad tšuktši tüdrukud enne külast lahkumist.

Mehel oli külm, sest kolmandat nädalat järjest sadas vihma ja tema riided ei olnud nii ilmastikukindlad kui kaaslasel. Tšuktšid kutsusid teda Jeloks, sest ka nende keeles puudus täht $\ddot{u}$.

Peab ütlema, et Ülo oli oma nimega rahul, kuna temale olid tuttavad tüdrukud ütelnud, et Jelo tähendab tšuktši keeles sõpra. Hiljem selgus, et tegelikult tähendab tšuktšikeelne sõna jelo nii ema- kui isapoolseid tädi- või onupoegi, samuti veresugulasi. 
Kutsumegi teda edaspidi selle nimega.

Eemal sõi kari suurusega 3500-4500 põhjapõtra, mille suuruseks oli hinnanud sopkal istuv tšuktš 4221 põtra.

Ülelugemine toimus järgmiselt. Mees seisis sopka otsas kivil. All liikus kiiresti mööda põdrakari. Ejgeli vehkis käega ja luges: «10, 20, 30... 100, 200... 1000 jne. Täpselt 4221 põhjapõtra ja mitte ühtegi rohkem. Halb aasta on olnud. 300 looma vähem kui möödunud aastal.»

Kuigi Jelole jäi niisuguse lugemise täpsus arusaamatuks, kuna põhjapõdrad olid tihedas karjas sadade kaupa möödunud, ei hakanud ta vastu vaidlema. Oma tšuktši keele suure oskusega ta kiidelda ei saanud, ning pealegi oli tal ükskõik, kas neid loomi oli natukene rohkem või vähem.

Kuna vihma sadas, siis oli põdrakari rahulik. Sääsed ja parmud selle ilmaga ei lennanud ja seetõttu oli karjustel vähem tööd.

Tavaliselt juunis-juulis oli sääski, parme ja kiine mustmiljon. Augustis läks olukord paremaks, siis oli putukaid vähem. Pärast 21. augustit, kui esimest korda jälle lund sadas, kadusid nad peaaegu üldse ära.

Jelo oli paar korda lugenud, mitu sääske jääb peopesa alla, kui käega püksipõlve pihta lajatada. Kõige rohkem oli ta ühe löögiga suutnud tappa 78 sääske. See oli muidugi rekordnumber, sest tavaliselt jäi peo alla umbes viiskümmend sääske.

Tegelikult ei olnud sääsed kõige hullemad. Palju vastikumad olid nõndanimetatud maskerad. Need olid tundra kihulased, kes tungisid läbi kõige väiksematest aukudest ja pragudest. Nende hooajal oli vaatamata nägu katvale sääsevõrgule Jelo kael ja kõrvatagused nende mürgistest hammustustest nii paistes, et pead sai pöörata ainult koos ülakeha pööramisega.

Tšuktšid rääkisid, et mõned vene geoloogid olevat tundras maskerade hammustustest päris segi läinud. Mõned olevat võtnud ennast isegi alasti, püherdanud veelompides ja jooksnud tundrasse, kust neid hiljem surnuna oli leitud.

Vene piirivalvuritel pidid hammustustest esimesel teenistusaastal jalad nii paiste minema, et saapad tuleb hospidalis noaga jalast lõigata, kui nad sinna ravile viiakse.

Vihm oli aga Jelo riided täiesti läbi niisutanud. Vesi oli isegi läbi riiete alla saabastesse nõrgunud ja need lirtsusid käimisel ebameeldivalt.

Külma tõttu tõusis Jelo ja hakkas põtru kokku ajama.

«Hackuu, hackuuu, hack, hack, hack,» kõlas tema hüüe sopkade vahel.

Põdrad reageerisid koheselt hõigetele ja hakkasid kokku jooksma. Ainult üks vastik elajas ei kuulanud käsku. Loom oli peidus ja ainult tema pruun selg paistis kääbusseedermänni tagant. Jelo otsis paraja kivi ja lennutas selle põõsas oleva looma suunas. Tavaliselt ta loomi kividega ei loopinud, aga vihma tõttu polnud ta just kõige paremas tujus.

Kivi tabas looma täpselt keset selga.

Jooksupanemise asemel loom röögatas ja tormas teda häirinud inimese suunas. Selgus, et põõsas oli istunud karu, kes oli oodanud, et mõni põder paraja kauguse peale tuleb, et siis sellest endale parajat lõunasööki saada. Kiiresti läbis ta mõnikümmend meetrit ja varsti seisis ta Jelost seitsme meetri kaugusel kahel käpal püsti ja urises valjusti.

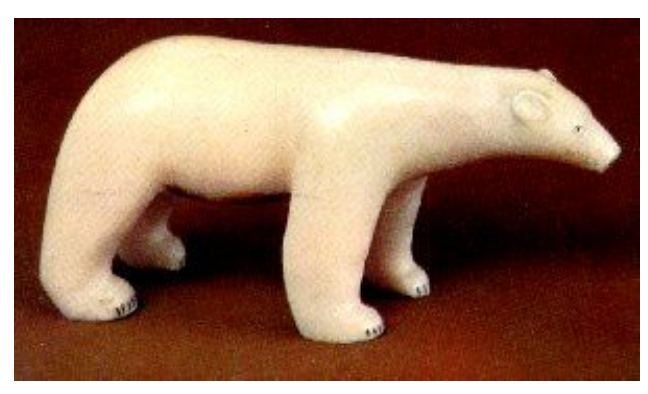


Ejgeli oli vahepeal üles ärganud ja hõikas: «Jelo, tule kohe ära!»

Jelole meenus vana tšuktši jahimehe Utteli õpetus, kes oli ütelnud: «Kui karu tuleb sinu suunas, siis ära talle kunagi selga näita, sest muidu oled sa kadunud mees. Karule meeldib inimesele selja tagant kallale tungida ja kui sa ei sure, siis skalbist oled ilma kindlasti. Kõige parem oleks, kui sa tema suunas karjudes jookseksid, siis karu hakkab kartma ja jookseb ära. Või möödu temast külje pealt, aga pea meeles - ei tohi mitte kunagi seljaga karu poole jääda.»

Seetõttu ei julgenud Jelo karule selga pöörata. Ta mõtles, et pidid nad ilma püssita välja tulema. Püss oli jäänud telki. Ejgeli ei tahtnud vihma tõttu relva kaasa võtta ja nüüd see siis oli. Karu tammub jalalt jalale ja hakka temaga peale, mis iganes soovid. Igaks juhuks võttis ta vöölt oma vägeva noa ja jäi seisma. Mõlemad vahtisid üksteisele otsa. Karu oli väga suur. Kahel jalal seistes ulatus ta kolme ja poole meetrini. Tema suu oli pärani ja sealt paistsid suured kihvad. Külma ilma tõttu tuli karul suust väljahingamisel auru. Karu seisis ja mörises.

«See on lihasööja grisli,» mõtles Jelo, «sellepärast ta nii suur ongi. Need pidid eriti ohtlikud olema.»

Ta seisis nuga käes ja vahtis karule silma. Karu urises ja tammus jalalt jalale.

Vahepeal oli ka Ejgeli sopka otsast alla jõudnud ja tuli Jelo selja tagant lähemale. Jelo kõrvale jõudes, asetas ta oda enda jalge ette ja ütles: «Pane kohe nuga maha. Ruttu!»

«Hull oled või?» ütles Jelo talle vastu.

«Tee ruttu, aega ei ole,» kostis tšuktš.

Jelo asetas noa samblale ja astus pool sammu tagasi, nii et Ejgeli jäi temast natukene ettepoole.

Ejgeli kummardus ettepoole, siis ajas ennast sirgu, vaatas karule otsa, tõstis oma käed üles ja hakkas monotoonselt rääkima:

Karu ära ole paha.

Me ei tee sulle mitte midagi paha.

Me oleme ühest verest, sina ja mina.

Karu mine ära.

Karu ära ole paha.

Me ei ole teinud sulle mitte midagi paha.

Me oleme ühest soost, sina ja mina.

Karu mine ära.

Karu ära ole paha.

Me ei ole teinud teie rahvale midagi paha.

Me joome ühest jõest, sina ja mina.

Karu mine ära.

Karu ära ole paha.

Me oleme küll esivanematele ande toonud.

Me oleme üks rahvas, sina ja mina.

Karu mine ära. 
Karu kuulas tähelepanelikult talle räägitavat juttu. Ta urin jäi vaiksemaks ja ta jälgis Ejgeli tegevust. Mees rääkis monotoonselt. Tema käed olid kogu aeg üles tõstetud. Ta vibutas oma ülakeha ette-taha, ise kogu aeg teraselt silmi karul hoides.

Pärast esimest salmi istus karu maha. Ta kuulas huviga talle räägitavat juttu, kallutades pead kord ühele poole, kord teisele poole. Kas selles liigutuses väljendus heakskiit tšuktšide tegevusele või vangutas ta uskumatult pead, see jäigi arusaamatuks, aga pärast kolmandat salmi noogutas ta nagu arusaaja peaga, laskus neljale jalale, keeras selja ja hakkas ära minema.

Tšuktši karjalaika, kes siiamaani oli hirmunult kiunudes meeste selja taga passinud, sai sellest julgust ja tormas klähvides karu suunas. Kord oli ta vasakul, kord paremal pool karu, kord haukus otse karu selja taga.

Karu püüdis koera liikumist jälgida, aga selle suure liikumiskiiruse tõttu tundus see võimatu olevat. Sellest aru saades hakkas karu jooksma, algul aeglaselt, pärast, kui koer talle siiski järgnes, üha kiiremini ja kiiremini, kuni ta nagu kiirrong läbi põõsaste tormas. Koer püüdis karu jälitada, aga jäi varsti tollest kaugele maha.

«Karu kardab, et teda sabast sikutatakse,» sõnas Ejgeli oma oda maast üles korjates.

Sopkade vahel kaikus Jelo hüsteeriline naer, kes tundis tohutut pingest vabanemist.

Nad ajasid karja kokku ja tegid lõkke üles. Jelo uuris tšuktšilt, mida too karule oli rääkinud.

Ejgeli seletas asja ja lisas, et kui sa seda juttu oleksid rääkinud tangide (venelaste halvustav nimetus) või eesti keeles, siis oleks metsloom su nahka pannud, sest eriti tangide keelt karud ei kannata. Metsarahvaga on alati võimalik ära leppida. Karud on ju loomanahka riietatud inimesed. Nad on nagu šamaanid, kes juba kaugelt mõistavad inimeste kavatsusi. Nendest ei tohi halvasti kõnelda, sest muidu hakkavad nad tegema karjale kurja.

Ja vaata, et sa kunagi põtru ei vannu ja ei karju, et "susi teid söögu», sest sellega tood sa põdrakarjale tohutu needuse kaela. Nimelt olevat halvad vaimud ketljad või kelid võimelised ennast huntidesse peitma ja sellise sõnumisega annaksid sa karja kelide meelevalda.

Ketljasid või kelesid pidi olema kolme liiki.

Ühe grupi moodustavad eriti kurjad vaimud, kes elutsevad kusagil kõiksuses. Nad liiguvad ringi ja jahivad inimeste kehi ning hingi. Nad segavad ennast pidevalt inimeste ellu ja on neile kõige tähtsamad. Nemad levitavadki taude ja katke, ning on võimelised hävitama terve suguharu. Põhiliselt tulebki ära teenida just nende vaimude rahulolu, et nad ei teeks sulle paha.

Teises grupis on vaimud, kes kuulevad šamaani bubini

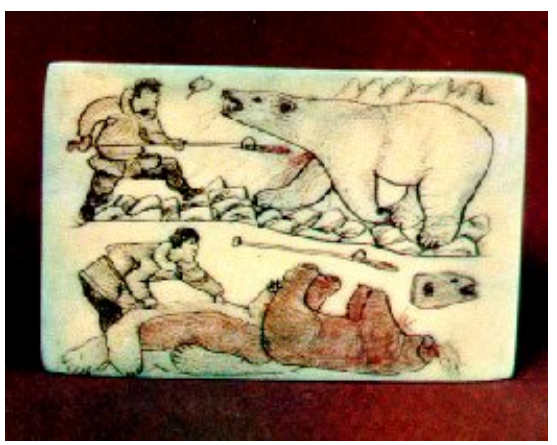
kutsuvat häält ja ruttavad talle appi, et abistada teda inimeste ravimisel. Nad aitavad šamaani tema rännakutel üla- või alailma.

Kolmandad on kusagil ei-tea-mis-maal elavad vaimud, kellega tuleb aeg-ajalt, aga mitte eriti sageli võidelda.

Üldiselt võivad ketljad võtta endale mitmeid kujusid. Ta võib olla mingi asi, loom või inimene.

Seega on ketlja - paha vaim - väga sarnane meie eesti mütoloogia paha tegelase kuradiga. 
Mõlemad võivad seega esineda sellisel kujul, nagu tahavad, ilmuda inimese, looma või mingi asjana.

Mõlemad, nii kurat kui ka ketlja on eristatavad tavalisest loomast või inimesest mingi erilisuse tõttu, mille poolest nad on enamasti ka ära tuntavad.

Selleks võivad olla ketljal loomana näiteks suured kõrvad, ebaloomulik pea, eriline silmade asetus. Tihti võib olla tal ainult üks silm, liiga suured mingi teise looma kõrvad või ta käitub erinevalt sellest, kuidas need loomad tavaliselt käituvad.

Ketlja võib võtta ka mõne asja kuju. Asjad muudavad siis iseenesest oma asukohti. Ketljal pidi olema võime võtta endale isegi kivi kuju, kui ta sulle tahab mägedes pähe prantsatada. Kivid võivad hakata iseenesest liikuma ja surmata ohvreid. Mõningal määral sarnaneb ketlja sel juhul poltergeistiga.

Inimesed käituvad imelikult. Kui ketlja on võtnud inimese kuju, siis on selleks tavaliselt läänest tulnud inimene. See ei tähenda muidugi mitte ainult venelast, vaid kõik halb tuleb lihtsalt läänest ja hea idast. Tuleb ju valguseandja päike idast ja kaob läände.

Matthias Johann Eisen kirjutab «Eesti mütoloogias»:

«Kuigi on oletatud, nagu tuleks esivanemate usundit dualismiks pidada, ei või me selle oletusega ometi leppida. Küll astub rahvajuttudes kurjuseprintsiip esimesse ritta, jah näib nagu tuleks esivanemate usundit koguni diabolotsentriliseks arvata, sest et kurat, vanapagan moondab nagu kõike enese ümber keerutavaks teljeks, kuid tõepoolest on ta võimu ometi piiratud, ta satub iga päev vastasvägede ohvriks.

Palju enam tuleb esivanema usundist animismiaate kandjaks arvata. Surnutest arenenud vaimud vajutavad kogu elule nagu pitseri peale. Need vaimud avaldavad tihti olude järgi paremat ehk pahemat iseloomu, mõnikord aga ainult paha iseloomu. Iseäranis õelad on kõik elus kurjad olnud isikud, aga ka ohvrita ehk matmiseta jäänud isikud, viimased ometi mitte alati.

Niisuguseid vaimusid hüütakse kurjadeks vaimudeks, kurjadeks haldjateks, kuraditeks.

Juba kuradi nime mitmuses tarvitamine tunnistab, et me seda nime ei või pärisnimeks (nomen proprium) pidada, vaid sugunimeks (nomen appellativum).

Neist kubiseb kogu loodus; ühtelugu kuuleme, et kuri vaim otsa saanud, kuid silmapilk esineb meile jälle teine.»

Eiseni kuradi ja kurjade vaimude juttude puhul võib paralleele tõmmata tšuktšide «ketljade» või «keledega».

Tšuktši usundi järgi on pidevalt vaja vaimusid meelitada, neile ohvreid tuua ja sellisel juhul on võimalik neid isegi abimeesteks muuta.

Kui mehed õhtul laagrisse jõudsid, rääkis Ejgeli kõigile, kuidas valge mees püüdis kiviga karu maha lüüa ja mis siis edasi juhtus.

«Hea, et sa tang ei ole, muidu peaksime täna sinu matuseid,» ütles Vatap, üks tšuktšidest, kes oli karjavalves koos Veemiga üle öö, «tangidel on selline halb hais juures, mida karud ei kannata. Nad katsuvad neid alati maha lüüa ja okste alla toppida, et siis hiljem roiskunud lihaga maiustada.»

«Ja ega sinu lõhn neile ka vist eriti ei meeldi,» lisas Veem. «Nad saavad kohe aru, kes on kes.» 